\title{
The Economy Society Improvement for Supporting Education in Indonesia
}

\author{
I Ketut Sudarsana ${ }^{1}$, Abdussakir $^{2}$, Yuniningsih ${ }^{3}$, Kustini $^{4}$, Ayu Esteka Sari ${ }^{5}$, Rinandita \\ Wikansari $^{6}$, Jamil Afrianto ${ }^{7}$, Karona Cahya Susena ${ }^{8}$, I Made Dharmawan ${ }^{9}$, I Gusti Agung \\ Istri Agung ${ }^{10}$, Abdul Rahman Suleman ${ }^{11}$ \\ \{liketutsudarsana@uhnsugriwa.ac.id\} \\ 1,9,10 Universitas Hindu Negeri I Gusti Bagus Sugriwa Denpasar, Bali, Indonesia, ${ }^{2}$ Department of \\ Mathematics Education, Graduate Program, Universitas Islam Negeri Maulana Malik Ibrahim Malang, \\ Indonesia, ${ }^{3,4}$ Faculty Economy And Business, Universitas Pembangunan Nasional "Veteran" Jawa \\ Timur, Surabaya, Indonesia, ${ }^{5}$ Department of Management, STIE Sakti Alam Kerinci, Jambi, Indonesia \\ ${ }^{6}$ Politeknik APP Jakarta, Indonesia, ${ }^{7}$ Department of accounting, Universitas Dehasen Bengkulu, \\ Indonesia, ${ }^{8}$ Departement of Management, Universitas Dehasen Bengkulu, Indonesia, ${ }^{11}$ Faculty of \\ Economics, Universitas Graha Nusantara Padangsidimpuan, Indonesia
}

\begin{abstract}
Economy role in education is an determined matter but it is not the primary role in education. Because there are many other matters which determine live or dead the education or whether the improved or retreated of the education. It's true that in modern world, and it gets more in post modern like our world now, almost all matters are controlled by money. The condition of education institution is on deficient condition, more over there are numbers of education institution which have low budget condition, even though with this condition, these institution still survice because the cooperation between the institution, society and parents are working very well, beside that, the institution has a big dedication to education. When they have low budget, they gathered all parents and society leaders to discuss and solve the problems in education fund. The spirit of parents and people to improve education are as best as the education institution. In the meeting of parents, society leader and education institutions, parents will directly say that they will donate fund to support education.
\end{abstract}

Keywords: Economy Society; Improvement; Supporting Education

\section{Introduction}

Education cannot be taken away from human life, because education will give porsperity for people and also education is a tool to create developement for a better life. Education is formed from the word educate, it means taking care and giving practice to understand moral and brain intelegency. Then, the base of educate is added with confix of -ion, so it is formed education which has the meaning of an activity to educate or deed to educate. Mudyaharjo said that education is every learning experience which occurs in every environment and in life time, in education contex, society is environment outside family environment and school environment [1]. Education that experienced in socienty has been started when children get bigger and stop having fully nurture from parents and they are outside school environment. There for, education impact has larger effect. 
Education is the series of interaction activity which aims to help the fully improvement of the pupils by face to face interaction between adult people and young people [2]. And the same words of Nawawi's view education definition got clearly definited about the essence of the education, he siad that education is aimed force to improve the personality and human ability whether inside of the school or outside of the school [3]. So, education is not only done at school, but it is also done outside of school and continuous in one life time or the term said "long live education.

The constitutions law of Republic of Indonesia which have many rules talking about education is Constitution of Republic of Indonesia number 20 yeat 2003. Because these constitutions can be said as the primary constitution of education, it menas that all thing which connected into education from pre-school until university is determined by this constitution law. The articles are important, more over which need deeper explanation and also as reference to develope education. In the article 1 verse 2 and verse 5, verse 2 is: National Education is educatiation based on Pancasila (five principle of Indonesia) and Indonesia Constitution 1945 which is rooted from regilious values, national culture of Indoneia, and responsive to demands of period changes. This constitution is required that education is formed from national culture and religious values, which based from Pancasila and Constitution of Indonesia 1945. By all means, all the education theories adn education practices which is applied in Indonesia can't be taken away from the Indonesian fact, and religion in Indonesia.

Trigged by big flow of modernization which requires to creat democratization in every life dimension, including education. Whether we want it or not, education has to managed in desentralization form by giving place as large as possible for the participation of society. As the impact of this, education becomes collaborative effort which involves society participation in it. The participation in this contex is a cooperation between citizen and government on planning, carrying out, keeping, and improving education activity. As a cooperation, so society is assumed of having aspiration which has to accomodate in planning process and running an educational program.

\section{Method}

This study used qualitative research methods. Collecting data needed using literature study as primary data. The research procedure was carried out through the collection of library data and field data which were processed through the reduction and display of data in organizing data according to their interests, then analyzed using qualitative descriptive method analysis.

\section{Result and Discussion}

Society role in educatio is contribution, donation, and people participation on supporting the effort of educational quality improvemet. Nowadays, planning, carrying out, and education monitoring involve society participation. The awareness of the importace of education can give hope and a better possibility in future. Drive many efforts and attention of all society level. This efforts create awareness of people participation [4] [2].

Society role, especially pupils' parents in running education is really low. Society participation isonly in fund generally, while other participation such as thoughts, moral, and 
items/services are less from attention. School accountability to society is weak. Schools don't think that they have to resposible their works to society, especially to parents' pupils, as one of main unsure which have interest with education (stakeholder).

In education contex, society is outside environtment of family environment and school environment. Education which is experienced in society has been started when children get bigger and stop having fully nurture from parents and they are outside school environment. There for, the education impact has larger effect. By education, we don't hope of forming human which is different and strenght for society, but human with a high quality, figure out, understand and they are able to build society. Thus, the purposes, contents, as well as education process has to be suited with the condition, character, wealltiness and the society developement. Society levels have the right to get good education. But they also have obligation to contribute their effort to education, whether is is fund, efforts, thoughts, energy or other kind of donation. People can involve on giving fund donation, building houses, education areas, educative technique such as studying-teaching process, provide theirselves to be educators, discussing the running of curriculum, talking about learning improvement, and so on. Society participation for school developement and education improvement is an objective fact which the understanding is determined by subjective condition of parents' pupils. There for, participation demands of the same understanding or objectiveness from school and parents on achieving school purposes. This can be understood that is not enough only school who understand, that participation which is the important part for school achievement on increasing school quality, because of the purpose of quality become hard to get if the understanding in the world of intrasubjective (pupils, parents, and teachers) show the gap of the quality understanding [5] [6].

There are many things that can be donated and be done by society to help manifesting a good quality of education, starts from using the services which is provided, to participation on making decission and also by paying donation or fund regularly. The making decission and taking action of wisdom should always try in order of taking action of wisdom involves the participation of society as many as possible, mainly on the taking action. While based on Surya, one of the education problems in Indonesia is limitedness funds and education tools, so the works of education don't run optimally [7]. The problems become more complex if we connect it with cumulation graduates because of less useful in society and working field, it is the impact of their low competencies. Quality and education results don't fulful hopes and what society needs or they have low competencies. Education system doesn't make society as the basic processual and it isn't formed from national social culture. Education runs outside social culture of society, so every thing which is planted by processing education is not some thing separated with life problems in the society.

According to Mulyasa, the conection of school ad society has purpose as followed.

a. Improving the quality of learning students and growing students.

b. Strenghten the purpose and also increasing life quality and people prosperity.

c. Awakening people to build relationship with school [8].

The constitution law of Republic of Indonesia number 20 year 2003 which contains about national education system, it is consisted of the participation of people in education in article 54 verse (1) Society participation in education are personal participation, group participation, family participation, organization provision participation, businessmen participation, and society organization on carrying and manage quality in enducation. Verse (2) society can be participated in many source of carrying out and the using of education results [9].

The education based of society is also in article 55 verse (1) people have right to run education with society bases in formal education and non formal education which is 
compatible with typical of religion, typical of social environment, and typical of culture for people benefits. Verse (2) the management of education which bases of developing and taking action of curriculum and education evaluating, and also management and funding is suited with national education standard. Verse (3) The fund of education management which bases of society is coming from the management, society, national government, region government, and or other source which doesn't not contractic with valid law constitution. Verse (4) Education institution which base of society can get technical help, subsidy fund and other source by equatibly and equally from national government and or region government. The appearance of education paradigm which base of society is trigged by big flow of modernization which creates democratization in every dimension of human life, including in education field. As the impact of this, education become the collaborative effort which involves people participatio in it. Participation in this contex is cooperation between citizen and government on planning, carrying out, keeping, and developing education activity. As a cooperation, so society is assumed having aspiration that should be accomodated on planning process and managing an education program. Thus, the educator (involved parties) have to do accountabilities (responsbility) to society. According to Sagala, accountabilities can improve national unity and also answer the demands of education for society. Management of accountability on society will grow the inovation and autonomy and making education which bases of socienty. To fulfil the education output which is suited with the demands and needs of society required a good quality of education. If we look at the education quality in our country nowadays, our education still faces some problems [10].

The developement of macro economy also impacts to education field. There are many wealthy people are disposed to be adoptive father so the children from poor family can go to school, whether it is from self intuition or appealing from government which is never stop. The attitude and action like this is very praiseworthy, it is not only has humanity side, but also it helps government successing 9 years school obligation. They have giving a part of their money to charity for needed people. This action is needed to be copied by other wealthy people but they haven't been adoptive fathers. Other delight improvement in education field is the fulfilling garuda system in education. This education can occur in numbers of education institution, it is cooperation between school and businessmen on teaching process the pupils is because the awareness of company leader or industry leader about how important education is. This awareniss is also appear because a half of their business has great achievement and has given much profit. They have begun realize that as a businessmen, more over they have obligation to give beside accepting graduates from education institution is wrong. The donation which is really worthy for education is get involved managing education process it self in the limit of their ability.

Life school level or universities is determined by economy condition. Rich Schools or rich universities can live more unimpended because of all kind financing will be given as it should be. There also schools have leftover fund which is stored in the bank in order to get interest as additional fund. In the other side, poor schools or poor universities are really hard to move, hiring teachers or hirig lecturers are hard to do, it is not included building houses or buying modern tools for learning, it is some thing impossible to be done. Most of schools in Indonesia are weak economically. Even though all schools have their own building, but it is not fascinating and it has minimum learning tool, and also the prosperity of teachers and the lecturers are far from enough. 


\section{Conclusion}

The function of economy in education field is to help the flow of education process. It is not fund to be developed, it is not to get profit. Education economy has the same function with other education sources, such as teacher, curriculum, learning tools, and so on to achieve education mission, and all of them are coming from the improvement of pupils. Economy part of one educatio source which able to make pupils improvig affection, cognition, and skill. Beside as supporting of education process, education economy also has function as subject materials in economy matter in people's life.

It would be better if it is abstracted, as followed.

a) Education economy holds important role even though it is not the most important part on sucessing education mission.

b) The function of education economy is to support the continuity of education process and as school subject to form economic people.

c) The source of education funds beside from government or non government organizaion and society, education institution can take other sources as much as possible.

d) Education fund needs to manage profesionally, it is generally using SP4 and it is accounted with valid evidences.

e) Thus, the economy position in society to support education in Indonesia

\section{References}

[1] R. Mudyahardjo, Pengantar Pendidikan. Jakarta: PT Raja Grafindo Persada, 2007.

[2] H. Z. Idris, Pengantar Pendidikan. Jakarta: PT Gramedia Widiasarana Indonesia, 1992.

[3] H. Nawawi, Pengantar Administrasi Pendidikan. Pontianak: Aji Mas Agung, 1971.

[4] I. K. Sudarsana, "Peningkatan Mutu Pendidikan Luar Sekolah Dalam Upayapembangunan Sumber Daya Manusia," J. Penjaminan Mutu, 2016.

[5] S. Adiwikarta, Peran dan Strategi Dasar Pendidikan DalamPeningkatan Sumber Daya Manusia. Seminar Nasional Tentang UpayaPengentasan Kemiskinan di Desa Terpencil. Bandung: IKIP Bandung, 1994.

[6] N. Sumaatmadja, Pendidikan Pemanusiaan Manusia Manusiawi. Bandung: Alfabeta, 2002.

[7] K. U. Sukardjo, M, Landasan Pendidikan Konsep dan Aplikasinya. Jakarta: PT Rajagrafindo Persada, 2013.

[8] E. Mulyasa, "Manajemen dan kepemimpinan kepala sekolah," Jakarta Bumi Aksara, 2012.

[9] E. Mulyasa, "Kurikulum tingkat satuan pendidikan: Sebuah panduan praktis," Bandung PT Remaja Rosdakarya, 2007.

[10] S. Sagala, Manajemen Berbasis sekolah dan Masyarakat. Strategi Memenangkan Persaingan Mutu. Jakarta: PT Rakasta Samasta, 2004. 